\title{
THE PRESENCE OF STATE ACTION IN UNITED STEELWORKERS V. WEBER
}

In United Steelworkers $v$. Weber ${ }^{1}$ the Supreme Court decided that an affirmative action plan designed to eliminate conspicuous racial discrimination did not violate Title VII of the Civil Rights Act of $1964 .^{2}$ Weber, who had been denied admission to his plant's training program even though less senior black employees had been accepted, asserted that he had been discriminated against because he was white. Weber did not seriously pursue a cause of action under the fifth amendment of the Constitution; ${ }^{3}$ as a result, the Court did not consider whether the

I. 443 U.S. 193 (1979).

2. 42 U.S.C. $\S \S 2000$ e to $2000 \mathrm{e}-16$ (1976).

3. U.S. CoNsT. amend. V provides that "[n]o person shall . . be deprived of life, liberty, or property, without due process of law . . ." In Bolling v. Sharpe, 347 U.S. 497 (1954), the Supreme Court held that the fifth amendment's due process clause includes a requirement of equal protection and places the same constitutional limitations on federal action as the fourteenth amendment's equal protection clause places on state action. See Colorado Anti-Discrimination Comm'n v. Continental Air Lines, Inc., 372 U.S. 714, 72 I (1963). See also Schneider v. Rusk, 377 U.S. 163,168 (1964).

Unlike the plaintiffs in Davis v. Passman, 442 U.S. 228 (1979), and Regents of the Univ. of Cal. v. Bakke, 438 U.S. 265 (1978), who asserted that they were entitled to constitutional protection, Weber relegated this argument to a footnote. Weber asserted:

A theoretical constitutional issue could arise if the Court determined that Congress in Title VIl, or by its subsequent failure to enact amendments to Title VII, authorized the executive branch to require the imposition of racial preferences. However, this case does not involve a government-imposed quota, even though the regulations and requirements of the OFCC were a motivating force in the decision of Kaiser and USWA to institute the 50 per cent quota.

Brief for Respondents at 46 n.186, United SteeIworkers v. Weber, 443 U.S. 193 (1979).

In Davis a United States Congressinan fired a female assistant because he decided "that it was essential that [the assistant] be a man." 442 U.S. at 230 . In a five-to-four decision, the Suprene Court held that the assistant could bring an action for damages directly under the due process clause of the fifth amendment. Id. at 248-49.

In Bakke the Medical School of the University of California at Davis rejected a white applicant. The applicant contended that the admission committee's affirmative action pohicies unconstitutionally discriminated against him solely because of his race. The Supreme Court held that the admission policy was unconstitutional because it violated the equal protection clause of the fourteenth amendment. Justices Burger, Stewart, Rehnquist, and Stevens declined to reach the constitutional question, holding that 42 U.S.C. $\$ 2000 \mathrm{~d}$ (1976) prohibited the plan. Justices Brennan, White, Marsliall, and Blackmun found the plan compatible with the fourteenth amendment. Justice Powell concluded that the particular plan violated the fouteenth amendment. For an annlysis of the decision's implications, see Symposium: Regents of the University of California v. Bakke, 67 Calif. L. Rev. I (1979). See also Tribe, Perspectives on Bakke: Equal Protection, Pro. 
state action in the case was sufficient to trigger the equal protection component of the fifth amendment's due process clause.

Fullilove v. Klutznick, ${ }^{4}$ decided last term, presented the Supreme Court with a "reverse discrimination" claim brought under the fifth amendment. The minority busmess provision of the Public Works Employnent Act of $1977^{5}$ requires that, absent an administrative waiver, at least ten percent of the federal funds granted for public works projects be used to procure services or supphies from businesses of which fifty percent or more is owned by members of minority groups. The Court held that the set-aside provision is constitutional.

Because of important distmctions between the Fullilove set-aside program and the Weber affirmative action plan, the question whether a Weber plan would survive a fifth amendment challenge remains open. ${ }^{6}$ The most important difference is that the Fullilove program was enacted by Congress. The Court defers to Congress in this area because the Constitution charges the legislative branch with providing for the general welfare of the Umited States and witl enforcing the equal protection clause of the fourteenth ainendment. ${ }^{7}$ The Court has held that Congress has the power to define violations of the equal protection clause and to remedy sucl violations. ${ }^{8}$ Although the use of racial and ethnic criteria led the Fullilove Court to scrutinize the set-aside provi-

cedural Fairness, or Structural Justice?, 92 Harv. L. Rev. 864 (1979); Van Alstyne, A Preliminary Report on the Bakke Case, 64 A.A.U.P. Bull. 286 (1978); Van Alstyne, Controversy: More on the Bakke Decision, 65 ACADEME 49 (1979).

4. 100 S. Ct. $2758(1980)$.

5. 42 U.S.C. \& $6705(f)(2)$ (Supp. II 1978).

6. The Supreme Court has recently granted certiorari in two cases involving constitutional attacks on affirmative action plans. See Johnson v. Chicago Bd. of Educ., 604 F.2d 504 (7th Cir. 1979), cert. granted, 100 S. Ct. 3055 (1980) (No. 79-1356); Minnick v. California Dep't of Corrections, 95 Cal. App. 3d 506, 157 Cal. Rptr. 260 (1979), cert. granted, 100 S. Ct. 3055 (1980) (No. 791213).

7. In Fullilove, the Court stated:

In Columbia Broadcasting System, Inc. v. Democratic National Comm. 412 U.S. 94, 102 . . . (1973), we accorded "great weight to the decisions of Congress" even though the legislation implicated fundainental constitutional rights guaranteed by the First Amendment. The rule is not different when a congressional program raises equal protection concerns. See, e.g., Cleland v. National College of Business, 435 U.S. 213 . . . (1978); Mathews v. De Castro, 429 U.S. 181 . . . (1976).

$100 \mathrm{~S}$. Ct. at 2772.

8. Katzenbach v. Morgan, 384 U.S. 641 (1966). In Katzenbach the Court held that Congress Lad the power to remedy past discrimination. In Fullilove, Justice Powell, concurring, stated: "Implicit in . . . [Katzenbach's] holding was the Court's belief that Congress had the authority to find, and had found, that members of this minority group had suffered governmental discrimination." 100 S. Ct. at 2786 (Powell, J., concurring). Justice Powell also recalled that in South Carolina v. Katzenbach, 383 U.S. 301, 308 (1966), the Court had noted that Congress has authority to define and provide remedies for violations of the fifteenth amendment. $100 \mathrm{~S}$. Ct. at 2786. 
sion strictly, ${ }^{9}$ the Court determined that Congress had acted within its constitutional authority. ${ }^{10}$ In contrast to the Fullilove set-aside program, the Weber affirmative action plan was impleınented pursuant to a collective bargaining agreeinent between private parties. ${ }^{11}$ Government agencies induced and approved the affirmative action plan, ${ }^{12}$ but Congress did not specifically authorize it. ${ }^{13}$ The Court would subject a plan coerced by government agencies to a more rigorous review than one enacted by Congress. ${ }^{14}$

This distinction, along with other differences between the Fullilove and Weber affirmative action plans, ${ }^{15}$ indicates that a constitutional attack on a Weber-type plan might still be successful. If presented with such a challenge, the Court would need to determine, as a threshold

9. Strict scrutiny is required even if the racial or ethnic classification has a remedial purpose. $100 \mathrm{~S}$. Ct. at 2771 . The Court stated:

Hcre we pass, not on a choice made by a single judge or a school board but on a considercd decision of the Congress and the President. However, in no sense does that render it immune froun judicial scrutiny and it "is not to say we 'defer' to the judgment of the Congress ... on a Constitutional question," or that we would hesitate to invoke the constitution should we determinc that Congress has overstepped the bounds of its constitutional power. Columbia Broadcasting, . . . 412 U.S. [94] at 103 [1973] . . . .

-..

Congress inay employ racial or ethnic classifications in exercising its Spending or other legislative Powers only if those classifications do not violate the equal protection component of the Due Process Clause of the Fifth Amendinent. We recognize the need for careful judicial evaluation to assure that any congressional program that employs racial or ethnic criteria to accomphish the objective of remedying the present effects of past discrinination is narrowly tailorcd to the achievement of that goal.

$100 \mathrm{~S}$. Ct. at 2772, 2776. The Court applied a two-step analysis. First, it determined that the objectives of the ininority business enterprise provision were within the power of Congress. Id. at 2772-75. Second, it decided that the "limited use of racial and ethnic criteria, in the context presented, is a constitutionally permissible ineans for achieving thc congressional objectives and does not violate the equal protcction component of the Due Process Clause of the Fifth Amendment." Id. at 2772, 2775-80 (emphasis omitted).

10. Id. at 2780 . The Court noted, however, that "the program may press the outer limits of congressional authority . . . Id. at 2781.

11. Unitcd Steelworkers v. Weber, 443 U.S. at 197.

12. See text accompanying note 27 infra.

13. Weber v. Kaiser Alummum \& Chem. Corp., 563 F.2d 216, 218 (5th Cir. 1977), rev'd sub nom. United Steelworkers v. Weber, 443 U.S. 193 (1979).

14. In Fullilove v. Klutznick, 100 S. Ct. 2758, 2777 (1980), the Court stated: "It is fundamental that in no organ of government, state or federal, does there repose a more comprehensive reinedial power than in the Congress, cxpressly charged by the Constitution with competence and authority to enforce equal protection guarantees."

15. There are two other significant distinctions betwcen Fullilove and Weber. First, the Fullilove program included a number of minority groups, yet permitted flexibility of admimistration. See 42 U.S.C. \$ 6705(f)(2) (Supp. II 1978). The Court stressed these features in Fullilove in upholding the set-aside program. $100 \mathrm{~S}$. Ct. at 2779-80. The Weber plan, on the other hand, applied only to blacks and mandated a strict racial quota. 443 U.S. at 199. Second, Fullilove involved a facial constitutional cliallenge to the Act, see $100 \mathrm{~S}$. Cl. at 2775 , whereas in Weber there was an attack on the apphication of the affirmative action plan, see 443 U.S. at 200. The Court probably would have examined the Fullilove plan more closely, and perhaps would have reached a different conclusion, had the plaintiff in that case been directly affected by the plan. 
matter, whether sufficient state action was present to raise fifth amendment questions. This Note argues that the government contacts with the defendants in Weber were sufficient to constitute state action and thus to trigger fifth amendment protections. These contacts included the National Labor Relations Board's involvement with Weber's union, the United Steelworkers of America; 16 the Equal Employinent Opportunity Commission's pressure upon Weber's employer, Kaiser Aluminum and Chemical Corporation, to institute affirmative action plans; ${ }^{17}$ and the Office of Federal Contract Coinpliance Programs' imsistence that private contractors seeking government contracts implement affirmative action plans. ${ }^{18}$ Although predicting the result of a constitutional challenge to a Weber-type plan is beyond the scope of this Note, an analysis of the facts in Weber and of the case law on state action demonstrates that a court should reach the constitutional issue if it is presented again in a similar case. ${ }^{19}$

\section{The FACTS OF WEBER}

The United Steelworkers of America and Kaiser Aluminum and Chemical Corporation entered into a collective bargaining agreement covering fifteen Kaiser plants, including the one that employed Weber. The agreement required Kaiser to train production workers to fill craft openings by establishing programs in which the trainees would be selected on the basis of seniority. The parties agreed to eliminate racial imbalance in Kaiser's craft work forces by reserving for blacks half the openings in a plant's prograin until the percentage of black craft workers in a plant was equal to the percentage of blacks in the local labor force. ${ }^{20}$ Pursuant to this plan, the Kaiser plant in Gramercy, Louisiana, selected seven black and six white craft trainees froin its production work force. The most senior blacks selected had less semiority than several rejected white production workers. Weber, one of the rejected white workers, mstituted a class action to obtain injunctive and monetary relief.21 He claimed that the affirmative action plan denied him the opportunity to participate in the training prograin solely because of

16. See text accompanying notes 75-134 infra.

17. See text accompanying notes 135-58 infra.

18. See text accompanying notes $159-75$ infra.

19. Weber's attorney did not vigorously assert Weber's constitutional rights apparently because he was confident that Weber would prevail on his Title VII claim. Furthermore, the attorney probably believed that if the Court found state action the federal government would be encouraged to assume a nore active role in the implementation of affirmative action plans.

20. 443 U.S. at 199.

21. Id. at $199-200$. 
his race, in violation of Title VII of the Civil Rights Act of 1964.22

Neither the district court ${ }^{23}$ nor the court of appeals, ${ }^{24}$ which both found in Weber's favor, discussed any constitutional issues. The Supreine Court, reversing the lower courts, agreed that the only question presented was the interpretation of Title VII: "[W] hether Title VII forbids private einployers and unions. fronı voluntarily agreeing upon bona fide affirmative action plans that accord racial preferences in the manner and for the purpose provided in the Kaiser-USWA plan."25 Justice Brennan, speaking for the Court, concluded froin the legislative history that Congress did not intend through Title VII to prohibit all voluntary race-conscious affirmative action. ${ }^{26}$

Both the district court and the court of appeals stated that there had been substantial government involveinent in the affirmative action plan. The district court found that if the Office of Federal Contract Compliance Programs and the Equal Employment Opportunity Coinmission had not exerted so nuuch pressure on Kaiser and the Steelworkers Umion, they would never have instituted the affirmative action plan: "satisfying the requirenents of OFCC, and avoiding vexatious litiga-

22. 42 U.S.C. $\$ \S 2000 \mathrm{e}$ to $2000 \mathrm{e}-16$ (1976).

23. Weber v. Kaiser Aluminum \& Chem. Corp., 415 F. Supp. 761 (E.D. La. 1976), affd, 563

F.2d 216 (5th Cir. 1977), rev'd sub nom. Umited Steelworkers v. Weber, 443 U.S. 193 (1979).

24. Weber v. Kaiser Aluminum \& Chem. Corp., 563 F.2d 216 (5th Cir. 1977), rev'd sub nom. United Steelworkers v. Weber, 443 U.S. 193 (1979).

25. 443 U.S. at 200 (emphasis added). The Court stated: "We emphasize at the outset the narrowness of our inquiry. Since the Kaiser-USWA plan does not involve state action, this case does not present an alleged violation of the Equal Protection Clause of the Fourteenth Amendment." Id.

Weber asserted that 42 U.S.C. $\$ 2000 \mathrm{e}-2$ (a) to -2 (d) (1976) makes it unlawful to discriminate because of race when selectimg apprentices for training programs. 443 U.S. at 199-200. Subsection (a) provides:

It shall be an unlawful employment practice for an employer-

(1) to fail or refuse to hire or to discharge any individual, or otherwise to discriminate against any individual with respect to his compensation, terms, conditions, or privileges of employment, because of such imdividual's race, color, religion, sex, or national origin; or

(2) to limit, segregate, or classify his employees or applicants for employment in any way which would deprive or tend to deprive any imdividual of einployment opportumitics or otherwise adversely affect his status as an employee, because of such individual's race, color, religion, sex, or national origin.

42 U.S.C. \& 2000e-2(a) (1976). Subsection (d) provides:

It shall be an unlawful employment practice for any employer, labor organization, or joint labor-management committee controlling apprenticeship or other training or retraining, includimg on-the-job training programs to discriminate against any individual because of his race, color, religion, sex, or national origin in admission to, or employment in, any program established to provide apprenticeship or other training.

Id. $\$ 2000 \mathrm{e}-3(\mathrm{~d})$.

26. 443 U.S. at 204-08. See Meltzer, The Weber Case: The Judicial Abrogation of the Antidiscrimination Standard in Employment, 47 U. CHI. L. REV. 423, $439-43$ (1980). 
tion by minority employees, were [their] prime motivations."27 Weber did not assert that the extensive government contacts provided him with a fifth amendment equal protection claim; yet these contacts were sufficient to constitute state action and thus to entitle Weber to invoke the rights guaranteed by the fifth amendinent. ${ }^{28}$

\section{Principles of State Action}

The rights guaranteed by the fifth and fourteenth annendments protect the individual from state aggression; "[i]ndividual invasion of individual rights is not the subject-matter of the amendinent." 29 Courts must therefore distinguish between individual and state action. ${ }^{30}$ State action clearly arises from state and local legislation and from actions of government officers that abridge individual rights. The distinction is less clear when state activity is mixed with private activity. The Supreme Court has found that state action can be present in three of these mixed situations: ${ }^{31}$ private performance of a governmental function; 32 judicial enforcement of a private agreenent; 33 and sigmificant government involvement with the conduct of private parties. ${ }^{34}$ Moreover, courts are more inclined to find state action in any of these three situations if racial discrimination has occurred. ${ }^{35}$ The Supreme Court has not developed a umform standard for finding state action. Generally, it sifts through the facts of a particular case to ascertam whether the totality of government activity is sufficient to constitute state action.

27. 415 F. Supp. at 765 . The district court also stated that the quota system "was prompted not only by [Kaiser's] desire to increase the percentage of its black craftsmen, . . . but also by its conceru about compliance with rules and regulations issued by the Office of Federal Contract Coinpliance . . . ."Id. Similarly, the court of appeals stated:

[T] he affirmative action complained of was not imposed by the judiciary; rather, this collective bargaining agreement was entered into to avoid future hitigation and to comply with the threats of the Office of Federal Contract Compliance Programs (OFCC) conditioning federal contracts on appropriate affirmative action. 563 F.2d at 218 .

28. See text accompanying notes $72-74$ infra.

29. Civil Rights Cases, 109 U.S. 3, 11 (1883).

30. See Note, State Action: Theories for Applying Constitutional Restrictions to Private Activity, 74 Colum. L. Rev. 656 (1974).

31. Magill v. Avonworth Baseball Conference, 516 F.2d 1328, 1331 (3d Cir. 1975).

32. See text accompanying notes $36-42$ infra.

33. See text accompanying notes $43-47$ infra.

34. See text accompanying notes 48-69 infra.

35. See text accompanying notes 70-71 infra. 


\section{A. Private Performance of a Governmental Function.}

The "white primary" cases ${ }^{36}$ illustrate the first mixed situation: private performance of a governmental function. The white primary cases involved various schemes to prohibit minorities from voting im primary elections. In Nixon $v$. Condon ${ }^{37}$ the Texas legislature enacted a statute delegating to the local Democratic Party's executive committee the power to determine voter qualifications for the Democratic primary election. The legislature enacted this statute in response to Nixon $v$. Herndon, ${ }^{38}$ in which the Supreme Court held that Texas could not forbid blacks to vote in primaries. The Deinocratic Party's executive committee continued the legislature's practice of excluding blacks from voting in primaries. The Supreme Court held that the state's delegation of authority to the Democratic Party constituted state action. The exclusion of blacks froin participating in the primaries thus violated the fourteenth amendment:

[The members of the committee] are not acting in matters of merely private concern like the directors or agents of busimess corporations. They are acting in matters of high public interest, matters intimately connected with the capacity of government to exercise its functions unbrokenly and smoothly. . . . The test is not whether the members of the Executive Committee are the representatives of the State in the strict sense in which an agent is the representative of his principal. The test is whether they are to be classified as representatives of the State to such an extent and in such a sense that the great restraints of the Constitution set limits to their action. ${ }^{39}$

Private performance of governmental functions also occurs im other contexts. In Marsh v. Alabama ${ }^{40}$ a company-owned town imposed criminal punishment on a person who distributed religious literature on its premises. The Court held that regardless of whether the corporation or a inunicipality owned the town, it was subject to constitutional limitations; the town could therefore not abridge first amendment rights. ${ }^{41}$ Although the Court has classified other activities as

36. See Terry v. Adams, 345 U.S. 461 (1953); Smith v. Allwright, 321 U.S. 649 (1944); Nixon v. Condon, 286 U.S. 73 (1932); Nixon v. Herndon, 273 U.S. 536 (1927).

37. 286 U.S. 73 (1932).

38. 273 U.S. 536 (1927).

39. Nixon v. Condon, 286 U.S. at 88-89. The Court may have been more willing to find state action in the primary cases because the infringement of the right to vote directly violated the rights guaranteed by the fifteenth amendment.

40. 326 U.S. 501 (1946).

41. Id. at 507. The Court stated:

We do not think it makes any significant constitutional difference as to the relationship between the rights of the owner and those of the public that here the State, instead of permitting the corporation to operate a highway, permitted it to use its property as a town, operate a "business block" in the town and a street and sidewalk on that busmess block. Cf. Barney v. Keokuk, 94 U.S. 324, 340 [1876]. Whether a corporation or a mu- 
governmental, it has been reluctant to place many activities performed by private parties into this category. ${ }^{42}$

\section{B. Judicial Enforcement of a Private Agreement.}

In Shelley v. Kraemer ${ }^{43}$ the Supreme Court establislied a second class of cases in which private activity may constitute state action subject to constitutional scrutiny. The issue in Shelley was whetler "judicial enforcement by state courts of restrictive covenants based on race or color" is state action. ${ }^{44}$ The Court held that a racially restrictive covenant could not be enforced in equity against a black purchaser because such enforcement would constitute state denial of equal protection:

The judicial action in each case bears the clear and unmistakable imprimatur of the State. We have noted that previous decisions of this Court have established the proposition that judicial action is not iminunized from the operation of the Fourteenth Amendment simply because it is taken pursuant to the state's conmion-law policy. Nor is the Amendment ineffective simply because the particular pattern of discrimination, which the State has enforced, was defined initially by the terms of a private agreement. State action, as that phrase is understood for the purposes of the Fourteenth Amendment, refers to exertions of state power in all forms. ${ }^{45}$

nicipality owns or possesses the town the public in either case has an identical interest in the functioning of the community in such manner that the channels of communication remain free. As we have heretofore stated, the town of Chickasaw does not function differently from any other town.

Id. at 507-08.

42. The Court has applied the governmental-function test in other private action cases. See, e.g., Food Employees Local 590 v. Logan Valley Plaza, lnc., 391 U.S. 308 (1968) (some shopping centers perform public functions), questioned, Hudgens v. NLRB, 424 U.S. 507, 518 (1976); Evans v. Newton, 382 U.S. 296 (1966) (private parks render mumicipal services). The Supreme Court seems, however, to be limiting the scope of the governmental-function test. In Hudgens v. NLRB, 424 U.S. 507 (1976), the plurality opinion of the Court would have overruled Logan Valley and held that a shopping center does not perform a public function. $C f$. Pruneyard Shopping Center v. Robins, $100 \mathrm{~S}$. Ct. 2035, 2041-42 (1980) (holding that a state constitutional provision giving individuals the right to solicit signatures and distribute pamphlets at a private shopping center does not violate the owner's property rights under the fifth amendment). Similarly, in Evans v. Abney, 396 U.S. 435 (1970), the Court in effect overruled Evans v. Newton, 382 U.S. 296 (1966). In Newton an individual devised to a mumicipality, in trust, a tract of land that was to be used as a park for whites only. Id. at 297. The Court held that the park services were municipal, so that the Constitution prohibited the park's discrimination. As a result of the Newton decision, the Supreme Court of Georgia ruled that it had become impossible to fulfill the intention of the testator and that the trust had therefore failed. Evans v. Abney, $224 \mathrm{Ga} .826,165$ S.E.2d 160 (1968), aff'd, 396 U.S. 435 (1970). The Supreme Court's affirmance placed primary emphasis on the testator's desire "that the park remain forever for the exclusive use of white people," and on the state's nonapplication of the cy pres doctrine. Id. at 447.

43. 334 U.S. 1 (1948).

44. Id. at 8 .

45. Id. at 20 (footnote oinitted). 
Although the broad principle enunciated in Shelley could implicate the state in numerous instances, the Court has not construed Shelley liberally. ${ }^{46}$ Generally, more than judicial enforcenent of a private contract is required before a court will find state action. ${ }^{47}$

\section{Significant Government Involvement with the Conduct of Private Parties.}

The Supreme Court has also found state action in cases in which the state has significant mvolvement with private defendants. For the requisite involvement there must be either jomt participation between the state and the private party in the activity, ${ }^{48}$ state authorization and encouragement of the private conduct, 49 or a "close nexus" 50 between the private conduct and the government. ${ }^{51}$

1. Joint Participation with the Private Party. In Burton v. Wilmington Parking Authority 52 a state agency built and owned a parking garage. The agency leased space in the garage to a public restaurant that refused to serve blacks. The Court determined that the state and the private party were joint participants in the discriminatory venture. The state had furnished gas and heat and had repaired the building's structural flaws. Moreover, the state and the restaurant had inutually benefited front this synrbiotic relationship:

Addition of all these activities, obligations and responsibilities of the Authority, the benefits mutually conferred, together with the obvious fact that the restaurant is operated as an integral part of a public building devoted to a public parking service, imdicates that degree of state participation and involvement in discriminatory action which it was the design of the Fourteenth Amendment to con-

46. See, e.g., Black v. Cutter Laboratories, 351 U.S. 292 (1956), in which the Court did not apply Shelley despite Justice Douglas's assertion in dissent that to allow an employer to dismiss an employee for communist activity would violate the first amendment. 351 U.S. at 302 (Douglas, J., dissenting). In Evans v. Abney, 396 U.S. 435, 445 (1970), the Court explicitly refused to apply Shelley to force defendants to keep open a park that was to revert to its donor upon the park's desegregation.

The Court has applied Shelley in other cases, however. For example, in Barrows v. Jackson, 346 U.S. 249 (1953), the Court reaffirmed Shelley's proscription of judicial enforcement of racially restrictive covenants. See also Hurd v. Hodge, 334 U.S. 24 (1948).

47. For example, in Weber, 443 U.S. at 209, the Court enforced the contract between the United Steelworkers and Kaiser despite Weber's assertion that such enforcement would violate the Shelley doctrine. See Brief for Respondents at 46 n.186, United Steelworkers v. Weber, 443 U.S. 193 (1979).

48. See text accompanying notes $52-58$ infra.

49. See text accompanying notes 59-64 infra.

50. Jackson v. Metropolitan Edison Co., 419 U.S. 345, 351 (1974).

51. See text accoinpanymg notes 65-69 infra.

52. 365 U.S. 715 (1961). 
demn. It is irony amounting to grave injustice that in one part of a single building, erected and maintained with public funds by an agency of the State to serve a public purpose, all persons have equal rights, while in another portion, also serving the public, a Negro is a second-class citizen ....53

The Court noted that within the lease or contract the state could have "affirmatively required [the private party] to discharge the responsibilities under the Fourteenth Amendment imposed upon the private enterprise as a consequence of state participation."54 This ability, in light of the "degree of state participation and involvement"ss in the discriminatory action, satisfied the state action requirenent of the fourteenth amendment. The Court cautioned, however, that "the peculiar facts or circumstances" of each case would determine whether government participation subjects a venture to constitutional requirements. ${ }^{56}$

In no case simce Burton has the Supreme Court found state action in a joint venture between private enterprise and government. Lower courts lave occasionally used the Burton analysis, ${ }^{57}$ but the restrictive trend in state action analysis ${ }^{58}$ tempers reliance on the Burton doctrine.

53. Id. at 724 .

54. Id. at 725 .

55. Id. at 724 .

56. Id. at $725-26$.

57. See, e.g., Janusaitis v. Middlebury Volunteer Fire Dep't, 607 F.2d 17, 23 (2d Cir. 1979); Briscoe v. Bock, 540 F.2d 392, 395 (8th Cir. 1976); Johnson v. Botica, 537 F.2d 930, 938 (7th Cir. 1976); Ginn v. Mathews, 533 F.2d 477 (9th Cir. 1976); Sarkees v. Wright \& Kremers, Inc., 433 F. Supp. 705, 706 (W.D.N.Y. 1977); Melanson v. Rantoul, 421 F. Supp. 492, $498-99$ (D.R.I. 1976), affd sub nom. Lamb v. RantouI, 561 F.2d 409 (1st Cir. 1977). See also De Malherbe v. International Union of Elevator Constructors, 476 F. Supp. 649 (N.D. Cal. 1979). In De Malherbe the plaintiff brought suit against a collective bargaining representative and local and international unions, alleging that they had violated his fifth amendinent rights by denying him adinission to a federally funded and inonitored training program because he was not a United States citizen. The court, finding that the defendants and the federal government were joint participants, placed particular significance on the role of the Office of Federal Contract Compliance in approving and fostering the citizenship requirement. Id. at 652-53. The court relied on Mathis v. Opportunities Industrialization Centers, Inc., 545 F.2d 97 (9th Cir. 1976), and Ginn v. Mathews, 533 F.2d 477 (9th Cir. 1976):

Ginn and Mathis together indicate that the Court of Appeals for the Ninth Circuit is willing to base a findimg of government action on government funding accompanied by substantial contractual restrictions without a detailed inquiry into the degree of administrative responsibility or control vested in the entity that provided the funding. In Ginn the court held that a Project Headstart program was a government instruinentality under Burton, since it received substantial funding from the federal government and, "[a]s might be expected, the generous purse was not made available without the ever-present strings attaclied."

476 F. Supp. at 661-62.

58. For a discussion of the Supreine Court's restrictive trend in state action analysis, see Note, State Action After Jackson v. Metropolitan Edison Co.: Analytical Framework for a Restrictive Doctrine, 81 DICK. L. REv. 315 (1977); Note, State Action and the Burger Court, 60 VA. L. REV. 840 (1974). 
2. State Authorization and Encouragement of Private Conduct. In addition to finding state action based on the joint participation of the state and a private party in a discriminatory venture, the Supreme Court has also found state action when the state has authorized and encouraged private discrimination. In Reitman v. Mulkey ${ }^{59}$ the Court considered an amendment to the California state constitution prohibiting the state from abridging "the right of any person . . . to decline to sell, lease or rent [his] property to such person or persons as he, in his absolute discretion, chooses."60 Although the amendment did not ostensibly involve the state in private discriminatory activity, the Court reviewed the decision of the California Supreme Court, and agreed with that court that the intent behind the amendment was "to overturn state laws that bore on the right of private sellers and lessors to discriminate." 61 Because the amendment in effect had authorized the private right to discriminate, and because the amendment's "ultimate impact" was to encourage private racial discrimination, ${ }^{62}$ the amendment had involved the state "m private racial discriminations to an unconstitutional degree."63 Indeed, private discrimination had become "one of the basic policies of the state." 64

3. The Close-nexus Test. In Jackson v. Metropolitan Edison Co.65 the Supreine Court considered a heavily regulated private utility that had terminated a customer's service without prior notice or a hearing before an impartial body. The customer asserted that the termination constituted state action and, as such, demed her due process of law. According to the custoiner, the state, in creating and regulatimg a public utility inonopoly, had either delegated a governmental function to a private party or significantly mvolved itself in a private party's activities. The Court rejected this contention, ${ }^{66}$ and held that the monopoly

59. 387 U.S. 369 (1967).

60. Id. at 371-72 (quoting CAL. Const. art. I, \& 26 (1964) (invalidated by Reitman v. Mulkey, 387 U.S. 369 (1967))).

61. 387 U.S. at $374,376$.

62. Id. at 376 .

63. Id. at 376-79.

64. Id. at 381.

65. 419 U.S. 345 (1974).

66. Id. at 353. The Court stated:

If we were dealing with the exercise by Metropolitan of some power delegated to it by the State which is traditionally associated with sovereignty, such as eminent domaim, our case would be quite a different one. But while the Pennsylvania statute imposes an obligation to furnish service on regulated utilities, it imposes no such obligation on the State. The Pennsylvania courts have rejected the contention that the furnishing of utility services is either a state function or a municipal duty. Girard Life Insurance Co. v. City of Philadelphia, 88 Pa. 393 (1879). . . . Doctors, optometrists, lawyers, Metropolitan, and Nebbia's upstate New York grocery selling a quart of milk are all in regulated busi- 
created by the state did not itself constitute state action. ${ }^{67}$ Instead, the Court formulated a test that requires the party alleging state action to show a close relationship between the state and the challenged action of the regulated entity:

It may well be that acts of a heavily regulated utility with at least something of a governmentally protected monopoly will more readily be found to be "state" acts than will the acts of an entity lacking these characteristics. But the imquiry must be whether there is a sufficiently close nexus between the State and the challenged action of the regulated entity so that the action of the latter may be fairly treated as that of the State itself. ${ }^{68}$

The Court failed to delineate standards that would be helpful in determining when "a sufficiently close nexus" exists between private and public activity to trigger constitutional scrutiny. It did indicate, however, that mere government approval of or permission for a private activity without a showing of government inducement or close participation did not constitute state action. ${ }^{69}$

nesses, providing arguably essential goods and services, "affected with a public interest." We do not believe that such a status converts their every action, absent more, into that of the State.

Id. at 352-54 (footnotes omitted).

67. The Court stated:

We also reject the notion that Metropolitan's termination is state action because the State "has specifically authorized and approved" the termination practice. In the instant case, Metropolitan filed with the Public Utility Commission a general tariff-a provision of whicl states Metropolitan's right to terminate service for nonpayment. . . . The District Court observed that the sole connection of the Commission with this regulation was Metropolitan's simple notice filing with the Commission and the lack of any Commission action to prohibit it.

Id. at 354-55 (footnote omitted). Moreover, the Court did not find that there had been a syinbiotic relationship or joint participation as in Burton v. Wilmington Parking Auth., 365 U.S. 715 (1961).

68. 419 U.S. at 350-51.

69. Lower court decisions since Metropolitan Edison have consistently distinguished between active participation or inducement and mere approval. Thus, in cases involving state grants-in-aid to private parties, the courts have not found state action unless the state has done inore than merely provide money and eugage in general regulation. See, e.g., Musso v. Suriano, 586 F.2d 59 (7th Cir. 1978) (nedicare funding of a nursing holne and a hospital; funding of a private university), cert. denied, 440 U.S. 971 (1979); Bethel v. Jendoco Constr. Corp., 570 F.2d 1168 (3d Cir. 1978) (government contracts); Greenya v. George Washington Umv., 512 F.2d 556 (D.C. Cir. 1975) (funding of a private university); Spark v. Catholic Univ. of America, 510 F.2d 1277 (D.C. Cir. 1975) (funding of a private university); Asclierman v. Presbyterian Hosp. of Pac. Medical Center, 507 F.2d 1103 (9th Cir. 1974) (funding for a hospital).

The courts require that the Metropolitan Edison nexus test be satisfied even if the state has soine additional control over the parties. Thus, in Hines v. Cenla Community Action Comm., 474 F.2d 1052 (5th Cir. 1973), the court found no state action although the private party, a community action agency, had received federal funding and had been required to carry out its program in accordance with the terms and conditions of the federal grant: "Sinee CCAC was not a public corporation controlled by the federal government, the plaintiff conld not be a federal employee. Therefore, CCAC as a private einployer had coinplete freedon of action and was not bound by the due process clause of the Fifth Amendinent." Id. at 1058. The plaintiff thus failed to establish the nexus between state involveinent and the alleged unconstitutional activity. The court indi- 


\section{State Action in Cases Alleging Racial Discrimination.}

Besides evaluating the extent of government contact, courts often look to the nature of a plaintiff's claim to determine whether state action exists in a private activity. Some lower courts have imdicated that a lesser degree of state involveinent is needed to invoke constitutional protection in cases involving racial discrimmation. ${ }^{70}$ This use of a more relaxed standard for state action in cases involving racial discrimmation is consistent with the standard of judicial scrutiny employed im claims asserted under the equal protection clause. Under the equal protection clause, classifications based upon race, alienage, or national origim are treated as inherently suspect while classifications based on other considerations are subject to less stringent review.71

\section{The Application of State Action Principles TO THE FACTS OF WEBER}

The federal government was extensively involved in the fornation of the collective bargaining agreement between Kaiser and the United Steelworkers of America that resulted in the Weber affirmative action

cated, however, that state action would have existed if the state had been involved in the daily supervision of the plan. Id.

Other cases also einphasize that whether state action exists depends upon the amount of government supervision over the private party. Several courts have held that a state's appointment of a majority of an institution's board of direetors is either determinative of state actiou or an important factor in establishing state actiou. See Downs v. Sawtelle, 574 F.2d 1 (1st Cir. 1978), cert. denied, 439 U.S. 910 (1979); O'Neill v. Graysou County War Memorial Hosp., 472 F.2d 1140 (6th Cir. 1973); Chiaffitelli v. Dettuner Hosp., Inc., 437 F.2d 429 (6th Cir. 1971); Mercdith v. Allen County War Memorial Hosp. Comm'n, 397 F.2d 33 (6th Cir. 1968); Aasum v. Good Sanaritan Hosp., 395 F. Supp. 363 (D. Or. 1975), affd, 542 F.2d 792 (9th Cir. 1976). Sone courts have indicated that the presence of even a minority of state appointees on a board of directors will be an important factor in determining state actiou. See Braden v. University of Pittsburgh, 392 F. Supp. 118 (W.D. Pa. 1975); Isaacs v. Board of Trustees, 385 F. Supp. 473 (E.D. Pa. 1974).

70. See, e.g., Granfield v. Catholic Univ. of America, 530 F.2d 1035 (D.C. Cir.), cert. denied, 429 U.S. 821 (1976); Girard v. 94th St. and Fifth Ave. Corp., 530 F.2d 66 (2d Cir. 1975), cert. denied, 425 U.S. 974 (1976); Rhode Island Chapter, Associated Gen. Contractors of America, Inc. v. Kreps, 450 F. Supp. 338 (D.R.I. 1978).

The court in Jackson v. Statler Foundation, 496 F.2d 623, 628-29 (2d Cir. 1974), commented on the tendency of some courts to regard state action claims in discrimination cases differently:

Prior case law while not directly controlling is not, of course, unenhightening. It is noteworthy that several courts lave considered claims that the activities of tax exempt organizations constitute "state actiou." Significantly, these cases divide into two groups: Where racial discrimination is involved, the courts have found "state action" to exist; where other constitutional claims are at issue (due process, freedoun of specch), the courts have generally concluded that no "state action" has occurred. . . . This dichotony is explained in part by the double "state action" standard which has beeu recognized-one, a less onerous test for cases involving racial discrimination, and a nore rigorous standard for other claims. . . . However, these results may also be explainable in terms of facts and circumstances peculiar to eacls case.

71. See, e.g., Frontiero v. Richardson, 411 U.S. 677 (1973); Loving v. Virginia, 388 U.S. 1 (1967). 
plan. Three fundamental connections between the government and the private parties provided sufficient government contacts to invoke the due process protections of the fifth amendment. First, the National Labor Relations Board certified the United Steelworkers of America as the bargaining representative for the agreement. ${ }^{72}$ Second, the Equal Employment Opportunity Commission exerted pressure upon private industry to implement affirmative action plans. ${ }^{73}$ And third, the Office of Federal Contractors Compliance Programs threatened to withhold federal contracts from Kaiser if it did not develop suitable affirmative action plans. ${ }^{74}$

\section{A. Involvement of the National Labor Relations Board.}

The agreenient between Kaiser and the Steelworkers containing the affirmative action plan was entered imto pursuant to a master collective bargaining agreement. ${ }^{75}$ As a result, there were three possible instances of state action. First, as a private bargaining representative, the United Steelworkers implemented national labor policy, thus arguably performing a governmental function. ${ }^{76}$ Second, the government arguably enforced a racially discriminatory contract. ${ }^{77}$ And finally, the government significantly involved itself with the conduct of the Umited Steelworkers of America. ${ }^{78}$

1. Implementing National Labor Policy: Private Performance of a Governmental Function. Section 7 of the National Labor Relations Act ${ }^{79}$ guarantees employees the basic rights of industrial self-determination: "the right to self-organization, to form, join, or assist labor organizations, to bargaim collectively through representatives of their own choosing, and to engage in other concerted activities for the purpose of collective bargaining or other mutual aid or protection." 80 These rights effectuate the national labor policy of minimizing industrial strife by encouraging the practice and procedure of collective bargaining. ${ }^{81}$

72. See text accompanying notes 75-134 infra.

73. See text accompanying notes $135-58$ infra.

74. See text accompanying notes $159-75$ infra.

75. United Steelworkers v. Weber, 443 U.S. at $197-98$. The collective bargaining process is authorized by the National Labor Relations Act, 29 U.S.C. $\$ \S 151-169$ (1976).

76. See text accompanying notes 79-97 infra.

77. See text accoinpanying notes 98-103 infra.

78. See text accompanying notes 104-18 infra.

79. 29 U.S.C. $\$ 157$ (1976).

80. Id.

81. See id. \& 151. 
In order to implement effectively the national labor policy embodied in section 7, the Act grants the employees' bargaining representative the exclusive right to represent the cmployees, once it has obtamed majority support. ${ }^{82}$ To protect minority imtercsts within the umion, Congress has imposed a duty of fair representation on this bargaining representative:

"Congress has seen fit to clothe the bargaining representative with powers comparable to those possessed by a legislative body both to create and restrict the rights of those whom it represents. . .." Steele v. Louisville \& N.R. Co., 323 U.S. 192, 202 [1944]. . . .

It was because the national labor pohicy vested unions with power to order the relations of employees with their enployer that this Court found it necessary to fashion the duty of fair representation. That duty "has stood as a bulwark to prevent arbitrary union conduct against individuals stripped of traditional forms of redress by the provisions of federal labor law." Vaca v. Sipes, 386 U.S. 171, $182[1967] .83$

The National Labor Relations Act also binds the bargaining representative to a policy of nondiscrimination in employment. ${ }^{84}$ The duty of fair representation thus requires the statutory representative to bargain in good faith for the imterest of all the inembers of the umit. ${ }^{85}$

82. Id. $\S 159$ (a). The principle of majority rule is central to the policy of fostering collective bargaining. See Wellington, Union Democracy and Fair Representation: Federal Responsibility in a Federal System, 67 YALE L.J. 1327, 1333 (1958).

83. NLRB v. Allis-Chalmers Mfg. Co., 388 U.S. 175, 180-81 (1967). The Supreme Court first recognized the statutory duty of fair representation in Steele v. Louisville \& N.R.R. Co., 323 U.S. 192 (1944). In Steele the agreement between the union and the employer provided that no more than 50\% of the firemen in each class of service within each seniority district would be black and that until that percentage was reached all vacancies would be filled by whites. The Court invalidated this plan, which effectively limited the opportunity for black employces, because the union had failed to represent thein fairly. The Court stated that although a statutory representative may enter into a contract that unfavorably affects some of its members, such unfavorable treatment inust be based upon "relevant differences." Id. at 203. "[T] he discriminations based on race alone," the Court concluded, were "obviously irrelevant and invidious." Id.

Although Steele interpreted actions imposed under the Railway Labor Act, 45 U.S.C. $§ \S 151$ 188 (1976), the doctrine of fair representation has been extended to actions under the National Labor Relations Act. See Wallace Corp. v. NLRB, 323 U.S. 248, 255-56 (1944). See generally M. SOVERN, Legal Restraints on Racial Discrimination IN Employment 158-59 (1966); H. Wellington, Labor and the Legal Process 129-84 (1968).

84. 29 U.S.C. § 158(b)(2) (1976); see Emporium Capwell Co. v. Western Addition Comm. Organization, 420 U.S. 50, 66 (1975). See also United Packinghouse Workers v. NLRB, 416 F.2d 1126, 1134 (D.C. Cir.), cert. denied, 396 U.S. 903 (1969).

85. See American Communication Ass'n v. Douds, 339 U.S. 382 (1950), in which the Supreune Court explained that "when authority derives in part from the Government's thumb on the scales, the exercise of that power by private persons becomes closely akin, in some respects, to its exercise by the Government itself." As a result, "the public interest in the good faith exercise of that power is very great." Id. at 401-02. 
A bargaining representative enjoys other benefits besides the exclusive right to represent the union. One of these is the rule that ties employees to the union they elect for one year after the election, during which no rival umion may file for an election to represent the workers. ${ }^{86}$ This contract-bar rule extends the protection against rival union challenges to the life of a collective bargaining agreennent, up to a maximum of three years. ${ }^{87}$

The National Labor Relations Board is vested with primary authority to ensure that the bargaining representative does in fact effectuate national labor policy. ${ }^{88}$ The Board has authority to conduct elections of representatives, ${ }^{89}$ to prevent unfair labor practices, ${ }^{90}$ and to enforce the duty of fair representation. ${ }^{91}$ The Board can, for exainple, decertify a bargaining representative and strip it of its exclusive right to represent the workers on finding that it has failed to represent minority employees fairly. ${ }^{92}$ The Board has also indicated that it will deny the benefits of the contract-bar rule to a bargaming representative that has practiced racial discrimination or allowed racial discrimination to appear on the face of the contract. ${ }^{93}$ Consequently, the Board has significant powers and duties to ensure that a bargaining representative such as the United Steelworkers of America acts in accordance with the mandates of the National Labor Relations Act.

A bargaining representative, as supervised by the National Labor Relations Board, thus has considerable responsibility for implementing national labor policy. Under Nixon v. Condon ${ }^{94}$ such private performance of a governmental function would appear to constitute state action, requiring constitutional review of a bargaining representative's actions. The Supreine Court has been reluctant, however, to find that private actions constitute performance of a governmental function. ${ }^{95}$

86. "No election shall be conducted pursuant to this subsection in any bargaining unit or any subdivision within which, in the preceding twelve-month period, a valid election shall have been held." 29 U.S.C. $\$ 159(\mathrm{e})(2)(1976)$.

87. See General Cable Corp., 139 N.L.R.B. 1123 (1962); Deluxe Metal Furniture Co., 121 N.L.R.B. 995, 998-1004 (1958).

88. 29 U.S.C. $\$ 160(a)(1976)$.

89. Id. $\S 159(\mathrm{c})(1)$.

90. Id. $\$ 160(\mathrm{a})$.

91. See Local Union No. 12, United Rubber Cork, Linoleum \& Plastic Workers v. NLRB, 368 F.2d 12, 19-20 (5th Cir. 1966), cert. denied, 389 U.S. 837 (1967). The Supreme Court neither recognized nor rejected the doctrine.

92. Independent Metal Workers Local I, 147 N.L.R.B. 1573 (1964); Pioneer Bus Co., 140 N.L.R.B. 54, 55 (1962); Hughes Tool Co., 104 N.L.R.B. 318, 321-24 (1953).

93. See Pioneer Bus Co., 140 N.L.R.B. 54, 55 (1962). See also St. Louis Cordage Mills, 168 N.L.R.B. 981 (1967).

94. 286 U.S. 73 (1932). See text accompanying notes 37-39 supra.

95. See note 42 supra and acconpanying text. 
Generally, such findings have been made only when private parties performed muncipal activities, as in Marsh v. Alabama, ${ }^{96}$ or became involved with voting qualifications, as in Nixon $v$. Condon.97 Thus a bargaining representative's role in effectuatimg national labor policy probably does not in itself constitute state action. Nonetheless, the collective bargaining agreement in Weber, when considered together with other government contacts, does indicate state action.

2. Judicial Enforcement of a Racially Discriminatory Contract. The Supreme Court in Shelley v. Kraemer ${ }^{98}$ held that judicial enforcement of a racially restrictive covenant constitutes state action denying equal protection of the laws. ${ }^{99}$ In Weber the collective bargaining agreement between Kaiser and the United Steelworkers of America contained a provision that restricted the opportunities of nonminority workers in favor of minority workers. Under the rationale of Shelley, judicial enforcenent of the racially restrictive contract in Weber slould constitute state action. In Ciba-Geigy Corp. v. Local 2548, United Textile Workers, ${ }^{100}$ a federal district court did apply Shelley in the context of enforcenrent of a collective bargaining agreeinent. In that case, the employer and the bargaining representative entered into a collective bargaining agreenient that contained a provision allowing the employer to schedule Sunday work for its employees. The petitioning employee claimed that such an agreenient violated rights guaranteed by the establishment clause of the first aniendment; the employer responded that no state action was involved. The court rejected the employer's response, stating that Shelley applied:

. . . I find the requisite government action furnished by this Court's action, under the reasoning of Shelley v. Kraemer . . . In Shelley, the Supreme Court held that a private agreement which would be unconstitutional if entered into by the state was valid, so long as its terms were voluntarily adhered to by private parties. The Court concluded, however, that any attempt to seek judicial enforcement of the agreement would sufficiently involve the state in an unconstitutional .activity so as to preclude enforcement. Both the Supreme Court and the First Circuit have acknowledged the applicability of Shelley to the enforcement of a collective bargaining agreement. Railway Employers' Department v. Hanson, 351 U.S. 225, 232 n. 4 . . . (1956); Linscott v. Millers Falls Co., 440 F.2d 14 (1st Cir. 1971), cert. demied,

96. 326 U.S. 501 (1946). See text accompanying notes $40-41$ supra.

97. 286 U.S. 73 (1932). See text accompanying notes 37-39 supra.

98. 334 U.S. 1 (1948).

99. See text accompanying notes $43-45$ supra.

100. 391 F. Supp. 287 (D.R.I. 1975). 
404 U.S. 872 [1971] . . . 101

The Ciba-Geigy decision is persuasive because enforcement of a collective bargaining agreement involves not only the court's action but also the supervision of the National Labor Relations Board. ${ }^{102}$ Thus, even greater government contact with the private activity exists in collective bargaining agreements than in Shelley, in which only judicial enforcement was involved. Nonetheless, the Supreme Court's reluctance to extend the Shelley doctrine ${ }^{103}$ indicates that it would probably not apply Shelley in the Weber context.

3. Government Contact with the Bargaining Representative. A third factor a court might consider in determining whether state action exists in a Weber situation is simply the extent of the government's involvement with the activity of the bargaining representative. A court could find state action, for example, based on the joint participation between the National Labor Relations Board and the bargaining representative. ${ }^{104}$ Alternatively, a court might rule that the monopoly granted the bargaining representative results in a close nexus between state and private activity, and thus constitutes state action. ${ }^{105}$

In Burton v. Wilmington Parking Authority 106 the Court concluded that there can be state action based on joint participation when the state and a private party have substantial contacts and they benefit mutually froun a joint activity. ${ }^{107}$ Arguably, the National Labor Relations Board is a joint participant with the bargaining representative: the representative plays an essential role in effectuating the national policy ${ }^{108}$ and furthers the policy of minimizing industrial strife by encouraging organized negotiations. ${ }^{109}$ Indeed, Congress imtended to rely upon the independently organized unions, which in turn must rely on the $\mathrm{Na}$ tional Labor Relations Board, ${ }^{110}$ to implement the national labor policy. Consequently, the relationship between the government and the representative is symbiotic, and thus similar to the relationship between the state and the restaurant in Burton.

101. Id. at 298 (citations omitted).

102. See text accompanying notes 88-93 supra.

103. See notes $46-47$ supra and acconpanying text.

104. See text accoinpanying notes 106-10 infra.

105. See text accompanying notes 111-18 infra.

106. 365 U.S. 715 (1961).

107. Id. at 721-26. See notes 52-56 supra and accompanying text.

108. See text accoinpanying notes 88-93 supra.

109. See text accompanying notes $79-81$ supra.

110. See text accompanying notes 88-93 supra. 
Even if the courts do not consider the bargaining representative and the government joint participants under Burton, they may still find state action under the nexus test enunciated in Jackson v. Metropolitan Edison Co. ${ }^{11}$ Under the nexus test a party seeking constitutional protection must show a close relationship between the state involvement and the challenged activity of the private entity, so that the private action may be treated as that of the state. ${ }^{112}$ Mere governmental knowledge or approval of the private activity will not constitute state action. ${ }^{113}$ Under Metropolitan Edison the state-granted monopoly im Weber would not itself satisfy the nexus test. ${ }^{114}$ There are, however, two significant distinctions between Metropolitan Edison and Weber, making a finding of state action in the Weber context more likely. First, a Weber situation involves an alleged demal of equal protection imstead of a violation of procedural due process as claimed in Metropolitan Edison. Courts are more willing to find state action when a plaintiff alleges racial discrimination. ${ }^{115}$ The second distinction involves the nature of the monopoly in Weber. In Metropolitan Edison the state agency was regulating a natural inonopoly that would exist regardless of state protection. ${ }^{116}$ The state regulation was intended "not to aid the company but to prevent its charging monopoly prices . . .."117 The Court found that this limited government involvement with the utility's termmation procedures did not constitute state action. The monopoly position of the statutory representative in Weber, however, was not the result of a natural monopoly, but was created solely by Congress's enactment of the National Labor Relations Act. ${ }^{118}$ This fact, together with the bargaining representative's role in effectuating national labor policy and the Board's close supervision of the representative, imdicates a much closer nexus between the government and the private party than there was in Metropolitan Edison. Moreover, if either the Federal Office of Contract Compliance Programs or the Equal Employment Opportumity Commission requires that a racially discrimmatory plan be imserted into the collective bargaining agreement, there is clearly a tight nexus and a need for constitutional scrutimy of the agreement.

111. 419 U.S. 345 (1974).

112. See id. at 351.

113. See note 69 supra.

114. See text accompanying notes $65-69$ supra.

115. See text accoinpanying notes 70-71 supra.

116. For discussion of natural monopolies, see T. Morgan, CASES AND Materials on EcoNOMIC REGULATION OF BUSINESS 5-23 (1976).

117. 419 U.S. at 367 (Marshall, J., dissenting).

118. See note 82 supra and accompanying text. 
4. State Action in Collective Bargaining Agreements. Several lower court decisions have found state action based on collective bargaining agreements when the government has authorized or encouraged potentially unconstitutional activity. In Linscott v. Millers Falls Co.119 the Court of Appeals for the First Circuit considered a collective bargaining agreement that provided for the creation and maintenance of a union shop, and that required all employees to pay dues or be discharged by the employer. One employee, a Seventh-Day Adventist, refused to pay dues because her rehion forbade contributing money to a union. She was subsequently discharged by her employer. In a suit for mjunctive rehef and damages, the employee claimed that the dues requirement deprived her of the right to free exercise of religion under the first amendment. The employer argued that the einployee had been discharged pursuant to a private agreement, and that therefore no state action was present. ${ }^{120}$

The court rejected the employer's argument. Concluding that section 14(b) of the Labor Management Relations Act ${ }^{121}$ constituted "federal approval" of a union shop, ${ }^{122}$ the court stated that the federal statute was "the source of the power and authority by which private rights [were] lost or sacrificed." 123 As a result, the employer's discharge sufficiently involved the government for the discharge to be subject to first amendment reyiew. ${ }^{124}$ The Linscott court's analysis thus resembled that of the Supreme Court in Reitman v. Mulkey, ${ }_{1}^{125}$ in which the Court concluded that a court should assess the potential impact of offcial action to determine if the state has sigmificantly mvolved itself with invidious discrimination. ${ }^{126}$

In Cubas v. Rapid American Corp. ${ }^{127}$ a federal district court indicated that although congressional authorization of a bargaining representative alone would not constitute state action, congressional authorization of specific discriminatory action by the representative would implicate the government in that activity. In declining to find

119. 440 F.2d 14 (1st Cir.), cert. denied, 404 U.S. 872 (1971).

120. 440 F.2d at 16-17.

121. 29 U.S.C. \& 164(b) (1976). Section 14(b) provides: "Nothing in this subchapter shall bc construed as authorizing the execution or application of agreements requiring membership in a labor organization as a condition of employment in any state or Territory in which such execution or application is prohibited by State or Territorial law."

122. 440 F.2d at 17.

123. Id. at 16 (quoting Railway Employees' Dep't v. Hanson, 351 U.S. 225, 232 (1956)).

124. 440 F.2d at 17.

125. 387 U.S. 369 (1967). See text accompanying notes 59-64 supra.

126. 387 U.S. at 380.

127. 420 F. Supp. 663,669 (E.D. Pa. 1976). 
state action in the mere certification of a union as a bargaining representative, the court stated:

Plaintiff relies primarily on Linscott v. Millers Falls Co., 440 F.2d 14

(1st Cir. 1971) a case in which the relevant actions by the union consisted of carrying out a procedure that Congress had specifically endorsed[.] 440 F.2d at $16 \mathrm{n}$. 2. The holding does not stand for the proposition that all actions taken by unions which are under the jurisdiction of the National Labor Relations Act are governmental actions. In the instant case, the Local's allegedly unlawful behavior was not taken in connection with efforts to comply with a federally favored procedure. Consequently, plaintiff's First and Fifth Amendnent claims . . . nust be dismissed . . . .128

Finally, in $N L R B$ v. Mansion House Center Management Corp. ${ }^{129}$ the court held that state action would exist if the National Labor Relations Board required an employer to negotiate with a bargaining representative that discriminated on the basis of race:

When a governmental agency recognizes such a union to be the bargaining representative it significantly. becolnes a willing participant in the union's discriminatory practices. Although the union itself is not a governmental instrumentality the National Labor Relations Board is. N.L.R.B. v. Nash-Finch Co., 404 U.S. 138 . . (1971). Moreover, here the Board seeks judicial cnforceinent of its order requiring collective bargaining in a federal court. Obviously, judicial enforcenient of private discrimination cannot be sanctioned. ${ }^{130}$

Under Linscott, Cubas, and Mansion House, state action thus exists when the National Labor Relations Act or the National Labor Relations Board coerces, directly encourages, or actively approves of a specific activity of the bargaining representative. ${ }^{131}$ Though it is unclear whether the Supreme Court would follow the rationale of these

128. Id.

129. 473 F.2d 471 (8th Cir. 1973).

130. Id. at 473 (citations omitted). For a discussion of the relationship of the National Labor Relations Board and racial discrimination by the statutory representative, see Axelrod \& Kaufman, Mansion House-Bekins-Handy Andy: The National Labor Relations Board's Role in Racial Discrimination Cases, 45 Geo. WASH. L. REv. 675, 682-88 (1977) (discussing legislative history); Leslie, Governmental Action and Standing: NLRB Certification of Discriminatory Unions, 1974 ARIz. ST. L.J. 35; Meltzer, The National Labor Relations Act and Racial Discrimination: The More Remedies, the Better?, 42 U. CHI. L. REv. 1 (1974); Note, Union Racial Discrimination: A Liberalized Siandard of Proof, 58 MiNN. L. REv. 335 (1973); Note, The Impact of De Facto Discrimination by Unions on the Availability of NLRB Bargaining Orders, 47 S. CAL. L. REv. 1353 (1974); 7 GA. L. REV. 770 (1973).

131. In Bell \& Howell Co. v. NLRB, 598 F.2d 136, 148-50 (D.C. Cir. 1978), cert. denied, 442 U.S. 942 (1979), the petitioner argued that the NLRB had violated the fifth amendinent by granting exclusive bargaining representative status to a union that had previously discriminated against women. The court rejected this argument and held that the Board's certification of a union did not violate the fifth amendment because the certification had not authorized or encouraged discrimination. 598 F.2d at 149 . Board certification imposed on the umion an affirmative duty not to discriminate, however, and subjected the union to sanctions for future discrimination. Id. Dis- 
cases, they nonetheless provide persuasive authority that state action is present in the Weber context. In Weber the National Labor Relations Board, the Equal Employment Opportumity Commission, and the Office of Federal Contract Comphance Programs approved ${ }^{132}$ or encouraged ${ }^{133}$ the racially restrictive contract. Thus, there was greater government involvement in Weber than in Cubas, in which the only government contact alleged was the general grant of the bargaining representative's powers. Even the Cubas court, though refusing to find state action, implied that specific government authorization of the private activity would constitute state action. ${ }^{134}$

\section{B. Involvement of the Equal Employment Opportunity Commission.}

The extensive pressure the Equal Employment Opportunity Commission exerted in Weber constitutes a second fundaniental connection between the government and the private parties who entered into the collective bargaining agreement. The Commission's primary function is to eliminate unlawful employment practices. ${ }^{135}$ In creating the Con1mission, Congress established a procedure whereby state and local agencies, as well as the national commission, would have an opportunity to settle disputes througli conference, conciliation, and persuasion before the aggrieved party is permitted to file a lawsuit. ${ }^{136}$ In the Equal Einployinent Opportunity Act of 1972, ${ }^{137}$ Congress amended Title VII to give the Commission authority to investigate charges of discrimination, to promote voluntary compliance with the requirements of Title VII, and to institute civil actions against the employer or union named

crimination by a certified union and tacit acceptance by the Board, the court indicated, would constitute state action:

Once certified, a union is invested with significant governmental powers, and passive acquiescence by the Board in union discrimination might well pose serious constitutional questions. Both the Court and the Board have avoided these difficulties by interpreting the Act to prohibit such discrimination, and by providing a wide variety of sanctions to enforce the prohibition.

Id. at 149-50.

132. The National Labor Relations Board knew of the racially restrictive contract in Weber and in effect approved that contract by not invoking its sanctioning powers. See text accoinpanying notes 88-93 supra.

133. The Equal Employment Opportunity Commission encouraged affirmative action by threatening to bring suit against industries without satisfactory affirmative action plans. See text accompanying notes 135-58 infra. The Office of Federal Contract Compliance Programs also promoted affirmative action by awarding lucrative government contracts to industries that implemented satisfactory plans. See text accompanying notes 159-75 infra.

134. 420 F. Supp, at 669.

135. Fekete v. United States Steel Corp., 424 F.2d 331, 334 (3d Cir. 1970).

136. Alexander v. Gardner-Denver Co., 415 U.S. 36, 44 (1974).

137. Pub. L. No. 92-261, 86 Stat. 103 (1972) (codified at scattered sections of 42 U.S.C. $\$ 2000$ e (1976)). 
in a discrimination charge. ${ }^{138}$ The Act uses the term "voluntary compliance" merely as a term of art; the term does not imply that there is private compliance without any government coercion. Rather, it means compliance in the absence of judicial intervention. ${ }^{139}$ The Commission's role is to encourage and, if necessary, to pressure private parties to make amends for past discrimination. ${ }^{140}$

Before Weber, the Equal Enıployinent Opportunity Commission had exerted significant pressure on Kaiser. Kaiser officials denied at trial that Kaiser had discriminated in hiring or proniotion; they stated, lowever, that the conipany was aware of its vulnerability to private or government lawsuits under Title VII. ${ }^{141}$ The officials explained that they had been defendants in Title VII hitigation involving other plants similar to the one at Graniercy. ${ }^{142}$ Furthermore, the Kaiser officials intimated that the government's industry-wide lawsuit agamst the steel industry in United States v. Allegheny-Ludlum Industries, Inc. ${ }^{143} \mathrm{mflu}-$ enced the Kaiser collective bargaining agreenent. ${ }^{44}$ Recognizing their potential vulnerability to such suits, the bargaining representative and Kaiser entered into the collective bargaining agreenient that iıcluded the affirmative action plan. ${ }^{145}$

138. Alexander v. Gardner-Denver Co., 415 U.S. at 44.

139. Id. at 44-47.

140. See United States v. Allegheny-Ludlum Indus., 517 F.2d 826, 843, 847, 868-69 (5th Cir. 1975), cert. denied, 425 U.S. 944 (1976). See generally Fekete v. United States Steel Corp., 424 F.2d 331, 336 (3d Cir. 1970); Bowe v. Colgate-Palmolive Co., 416 F.2d 711, 719 (7th Cir. 1969); Jenkins v. United Gas Corp., 400 F.2d 28, 32 n.8 (5th Cir. 1968).

Section 706a of the Civil Rights Act of 1964, 42 U.S.C. $\$ 2000 \mathrm{e}-5$ (b) (1976), provides:

[T]lue Commission . . . shall make an investigation . . . . If the Commission determmes after such investigation, that there is reasonable cause to believe that the charge is true, the Commission sliall endeavor to eliminate any such alleged unlawful employment practice by informal methods of conference, conciliation and persuasion.

Furthermore, section 706(3) of the Civil Rights Act of 1964, 42 U.S.C. $\$ 2000$ e-5(f) (1976), provides:

If within thirty days after a charge is filed with the Commission or within thirty days after expiration of any period of reference under subsection (c) or (d) . . . the Commission has been unable to secure from the respondent a conciliation agreemcnt acceptable to the Commission, the Commission may bring a civil action against any respondent not a government, governmental agency, or political subdivision nained in the charge.

The Equal Employment Opportunity Commission, a governmental agency, thus is involved in bringing about a voluntary settlement.

141. Petitioner's Brief for Certiorari at 6-7, United Steelworkers v. Weber, 443 U.S. 193 (1979).

142. Petitioner's Brief for Certiorari, supra note 141, at 6 .

143. 517 F.2d 826 (5th Cir. 1975), cert. denied, 425 U.S. 944 (1976). See text accompanying notes 146-54 infra.

144. Petitioner's Brief for Certiorari, supra note 141, at 6-7. Doubtless, the United Steelworkers officials were also familiar with Allegheny-Ludlum, for the United Steelworkers had been named a defendant in that case.

145. Petitioner's Brief for Certiorari, supra note 141, at 6-7. 
The specific pressures exerted by the Equal Employment Opportunity Commission were not indicated in the Weber record. The facts in Allegheny-Ludlum, however, illustrate the pressures that the Commission typically exerts upon private parties to encourage their implementation of effective affirmative action plans. In Allegheny-Ludlum the Secretary of Labor and the Commission sued nine major steel companies and the United Steelworkers of America alleging widespread hiring discrimination and job-assigninent discrimination on the basis of race, sex, and national origin. The complaint alleged that the companies had violated Title VII and Executive Order No. 11,246 ${ }^{146}$ by hiring and assigning employees on impermissible grounds and by restricting ethnic mimorities and females to low-paying and undesirable jobs. The complaint also charged the companies and the union with formulating, in the collective bargaining contracts, systems for promotion, layoff, recall, and transfer that deprived ininority and female employees of opportunities for advancement comparable to those opportunities enjoyed by white males. ${ }^{147}$ The Commission filed the complaint after six nionths of negotiations with the collective bargaiming representative, during which time the parties had attempted to establish voluntary compliance with Title VII. The Commission and the private parties settled after the defendants agreed to comply with Title VII..$^{148}$

An exammation of the provisions of the Allegheny-Ludlum consent decree illustrates the coercive and supervisory powers the Commission exercises when effectuating "voluntary compliance." For example, in order to avoid possible interpretative problems with the decree, the parties provided for enforcement procedures through a nationwide systein of implementation committees located within the local plants. Each committee included at least two union representatives and two coinpany representatives; in addition, the government was entitled to designate a representative to meet with any implementation committee.

146. 3 C.F.R. 339 (1964-1965 Compilation), reprinted in 42 U.S.C. $\$ 2000$ e app., at 1232 (1976). See text accompanying notes $159-68$ infra.

147. 517 F.2d at 834.

148. 517 F.2d at 834-35. Consent Decree I provided:

The substantive relief falls into three basic categories: (1) immediate implementation of broad plantwide seniority, along with transfer and testing reforms, and adoption of ongoing mechanisms for further reforms of seniority, departmental and line of progression (LOP) structures, all of which are designed to correct the continumg effects of past discriminatory assignments; (2) establishment of goals and timetables for fuller utilization of females and minorities in occupations and job categories from which they were discriminatorily excluded in the past; and (3) a back pay fund of $\$ 30,940,000$, to be paid to minority and female employees injured by the unlawful practices alleged in the complaint.

Id. at 835 . Also, Consent Decree II required the companies "to initiate affirmative action programs in hiring, imitial assignments, promotions, management trainimg, and recruitment of minorities and females." $I d$. 
The implementation committees were responsible for ensuring compliance with the consent decrees at the local plants and for establishing goals and timetables for affirmative action. ${ }^{149}$

A second committee, the audit and review committee, also ensured comphance with the consent decree. This committee, composed of five management members, five union niembers, and one Commission member, was created to enforce consent decrees that were not being implemented properly. ${ }^{150}$ The committee met regularly to oversee compliance and to resolve disputes, including those unresolved by the local implementation committees. One of the most significant clauses of the Allegheny-Ludlum consent decree provided that any issue not unanimously resolved by the audit and review committee could be brought by the dissenting member before a federal district court. ${ }^{151}$ Thus, if the government meniber of the committee did not approve of the execution of the consent decree, he could force litigation over the particular issue, in effect exercising a veto power. This is a powerful weapon to force the company and the bargaining representative to accept the Commission's interpretation of the consent decree. The audit and review committee was also responsible for modifying the consent decree if it appeared that the company was not properly remedying the past discrimination. ${ }^{152}$ If the Commission representative was at this point dissatisfied with the consent decree he could file suit in federal district court. ${ }^{153}$ Moreover, if he determined that the company was not eliminating past discrimination or that the parties were not complying with the consent decree, he could treat the alleged violations as new violations of Title VII (or of Executive Order No. 11,246). ${ }^{154}$ Thus, the government had significant coercive powers to ensure that the company executed an effective affirmative action plan.

The intensive network of control the Commission exercises in organizing and implementing affirmative action plans could prompt a court, in a Weber context, to conclude that the activity of the bargaming representative constitutes state action. A court might, for example, find elements of coercion in the Commission's activities, having an effect similar to the apparent government encouragement of discrimination in Reitman v. Mulkey. ${ }^{155}$ Or the Commission's involvement with affirmative action plans might lead to a finding of state action under the

149. Id.

150. Id.

151. Id. at $835-36$.

152. Id. at 836 .

153. $I d$.

154. Id. at 838.

155. 387 U.S. 369 (1967). See text accompanying notes 59-64 supra. 
nexus test of Metropolitan Edison. ${ }^{156}$ The Commission's use of coercion to induce private parties to establish affirmative action plans certainly indicates a "close nexus between the State and the challenged action." 157 Indeed, the Commission's use of a veto power, illustrated in Allegheny-Ludlum, ${ }^{158}$ reinforces the nexus between the government's actions and the challenged activity. By use of such a veto, the Commission can force the statutory representative and the company to accede to its demands. The nexus between the state and the challenged activity is certainly close.

\section{Involvement of the Office of Federal Contract Compliance Programs.}

The pressure the Office of Federal Contract Coinpliance Programs (OFCCP) exerts on employers and unions constitutes a third connection between the government and private parties in the Weber context. The primary responsibility of the OFCCP ${ }^{159}$ is to effectuate the directives of Executive Order No. 11,246, ${ }^{160}$ issued by President Johnson, which requires federally assisted construction contractors and their subcontractors to accord equal einployment opportunity in order to do business with the federal government. ${ }^{161}$ Executive Order No. $12,086^{162}$ and Executive Order No. 11,246163 authorize the Secretary of Labor to adopt rules, regulations, and orders to impleinent Executive

156. 419 U.S. 345 (1974). See text accompanying notes 65-69 supra.

157. Id. at 351. See text accompanying notes 68-69 supra.

158. See text accompanying notes $150-54$ supra.

159. The OFCCP "is responsible for establishing policies and goals and providing leadership and coordination of the Government's program to achieve nondiscrimination in employment by Government contractors and subcontractors ...." OfFICE OF tHE FeDERAL ReGisTer, NAtional Archives \& Records Service, General Services Administration, United States Government MANUAL, 1980/81, at 416 (1980). In June of 1975 the Office of Federal Contract Compliance was merged with two other Department of Labor equal employment programs to form the Office of Federal Contract Compliance Programs. [1978] 8 LAB. REL. REP. (BNA) § 421, at 201 .

160. 3 C.F.R. 339 (1964-1965 Compilation), reprinted in 42 U.S.C. $\$ 2000$ app., at 1232 (1976).

161. Exec. Order No. 11,246 requires affirmative action by government contractors and subcontractors with regard to various aspects of employment, including "employment, upgrading, demotion or transfer, recruitment or recruitment advertising; layoff or termination; rates of pay or other forms of compensation; and selection for training, including apprenticeship." 3 C.F.R. at 340 , reprinted in 42 U.S.C. $\$ 2000 \mathrm{e}$ app., at 1233 . The Secretary of Labor requires contractors and subcontractors meeting certain minimum standards to file annual employment reports, 41 C.F.R. $\S 60-1.7$ (1979), and to develop and implement written affirmative action programs that establish procedures, goals, and timetables for increased hiring and promotion of minorities and woinen, $i d$. $\S 60-1.40$.

162. 3 C.F.R. 230 (1979), reprinted in 42 U.S.C. $\$ 2000$ e, at 1453 (Supp. 11 1978).

163. 3 C.F.R. 339 (1964-1965 Compilation), reprinted in 42 U.S.C. \& 2000 e app., at 1232 (1976). 
Order No. 11,246 and its provisions. The OFCCP regulations require that government contracts of over $\$ 10,000,{ }^{164}$ if not exeinpt, ${ }^{165}$ include equal employment opportunity provisions. ${ }^{166}$ Contractors are, for example, prohibited from engaging in einployinent discrimination and are required to fulfill certain affirmative obhigations. ${ }^{167}$ Moreover, Executive Order No. 11,246 authorizes the Secretary of Labor to require periodic compliance reports from the contractor and to investigate the contractor to ensure compliance with those duties. ${ }^{168}$ To help implement the prograin, the OFCCP has established a systein of area coordinators to develop government-wide compliance prograins for labor market areas.

In Weber the OFCCP exerted pressure on Kaiser to institute the affirmative action plan. As the court of appeals noted,

the case . . . is unique in that the affirmative action complained of was not iniposed by the judiciary; rather, this collective bargaining agreement was entered into to avoid future litigation and to comply with the threats of the Office of Federal Contract Compliance Programs conditioning federal contracts on appropriate affirmative action. ${ }^{169}$

In fact, the involvement of the OFCCP was very similar to that of the Equal Employment Opportumity Commission in Allegheny-Ludlum. Both agencies were moving forces behind their respective affirmative action plans, for both could ensure coinphance with affirmative action objectives through coercive tactics. The Equal Einployinent Opportunity Commission could, for exainple, threaten the company with Title VII litigation; the OFCCP could threaten to withhold government contracts or to invalidate present contracts. ${ }^{170}$

Because they are determinative forces in private decision-inaking, these threats to withhold future contracts or to invalidate present ones

164. 41 C.F.R. $\S 60-1.5(a)(1)$ (1979). Also included in the OFCCP regulations are contracts or subcontracts that are bills of lading, that involve depositories of federal funds, or that involve financial institutions paying or issuing Uinted States savings bonds. Id.

165. 41 C.F.R. $\$ 60-1.5$ (1979). Most contracts under $\$ 10,000$, contracts and subcontracts for indefinite quantities, contracts for work performed outside the United States, contracts with state or local governments, contracts with certain cducational institutions, contracts to be performed near Indian Reservations, and contracts explicitly exempted by the Director of OFCCP are exempt. Id. \& 60-1.5(a) to $-1.5(\mathrm{~b})$. However, the Director of OFCCP nay withdraw any exemption to further the goals of Executive Order No. 11,246. Id. §60-1.5(d).

166. Id. $\S 60-1.4$.

167. Id.

168. 3 C.F.R. 339, § 203(c) (1964-1965 Coinpilation), reprinted in 42 U.S.C. $§ 2000 \mathrm{e}$ app., at 1232 (1976).

169. Weber v. Kaiser Aluminum \& Chem. Corp., 563 F.2d 216, 218 (5th Cir. 1977), rev'd sub nom. United Steelworkers v. Webor, 443 U.S. 193 (1979).

170. Exec. Order No. 11,246, \& 209(a)(5), 3 C.F.R. 339, 344 (1964-1965 Compilation), reprinted in 42 U.S.C. $\$ 2000$ e app., at 1232 (1976); 41 C.F.R. § 60-1.26(a) (1979). 
appear to constitute state action under Reitman v. Mulkey. ${ }^{171}$ Such threats necessarily would have a coercive effect upon private parties and encourage them to implement affirmative action plans. Adoption of the affirmative action plans could also constitute state action either under the Metropolitan Edison nexus test ${ }^{172}$ or under the theory that the OFCCP and the private parties are joint venturers as in Burton v. Wilmington Parking Authority. ${ }^{173}$ An employer's impleinentation of an affirmative action plan in response to an OFCCP threat to invahidate or withhold federal contracts indicates, at the very least, a close nexus between the OFCCP and the plan. Similarly, a finding of joint participation under Burton may be based on the relationship between the government and private contractors created by Executive Order No. 11,246 and the regulations promulgated thereunder. ${ }^{174}$ To execute the objectives of this executive order, the government must rely upon acceptance of the government contract by private individuals. At the same time, private contractors must depend upon federal contracts for their work. The result is a syunbiotic relationship between the government and private contractors, much like the relationship between the parking authority and the restaurant in Burton. ${ }^{175}$ The similarity of these two relationships is enhanced by the OFCCP's power to insert into government contracts whatever clause it desires concerning racial discrimination. Reitman v. Mulkey, the nexus test of Metropolitan Edison, and the joint participants test of Burton thus all imdicate that the activities of the OFCCP are, in the Weber context, sufficiently integrated with private decision-making to cause the private adoption of an affirmative action plan to be state action, subject to scrutiny under the fifth amendment.

\section{CONCLUSION}

In United Steelworkers v. Weber the Suprene Court held that an affirmative action plan that gave preference to black workers over white workers did not violate Title VII of the Civil Rights Act of 1964. Although the plaintiff in Weber did not seriously challenge the constitutionahity of his einployer's affirmative action plan, the government's involvement with the plan imdicates that sufficient state action existed to trigger constitutional review. Rather than applying a rigid formula

171. 387 U.S. 369 (1967). See text accompanying notes 59-64 supra.

172. See notes 65-69 supra and accompanying text.

173. 365 U.S. 715 (1961). See notes 52-58 supra and accompanying text.

174. See notes 159-68 supra and accompanying text.

175. See text accompanying notes 52-58 supra. 
to determine when state action exists, courts generally examine the particular facts or circumstances of a given case.

In Weber the government had three significant contacts with the affirmative action plan. First, the National Labor Relations Board's certification of the United Steelworkers of America as the exclusive bargaining agent for Kaiser workers, under several of the Supreme Court's state action tests, is sufficient to implicate the government im that representative's activities. Second, the Equal Employment Opportunity Commission's pressure to implement particular affirmative action plans also supports a finding that the Weber plan resulted from state action. Fimally, the Office of Federal Contract Comphance Progranis' threat to withhold or invahidate government contracts in the absence of affirmative action plans clearly constitutes the type of involvenient that has led soine courts to treat ostensibly private activity as that of the state.

Courts in the future are likely to address affirmative action plans in the Weber factual setting. These courts should subject such affirmative action plans to constitutional scrutiny. 